\title{
Is taTME delivering?
}

\author{
M. Gachabayov ${ }^{1} \cdot$ R Bergamaschi $^{1}$
}

Received: 10 February 2019 / Accepted: 16 February 2019 / Published online: 22 February 2019

(C) Italian Society of Surgery (SIC) 2019

Keywords Rectal cancer · Total mesorectal excision · Robotic surgery $\cdot$ Transanal surgery $\cdot$ Circumferential resection margin

The first rectal cancer excision was attributed to Jacques Lisfranc who performed the operation through a transanal approach, as was the custom of the day in the 1800s [1]. The transanal approach was further developed by Richard von Volkmann a few decades later [2]. Nowadays, the unfortunate state of affairs is that advancement in a career is no longer supported by the premise that crediting the founding fathers and doing justice to the literature has meaning. In that regard, transanal total mesorectal excision (taTME) seems to be grabbing the headlines. The rationale behind taTME steams from a reasonable concern for involved circumferential margins and incomplete quality of TME in obese males with low rectal cancer and bulky mesorectum in a narrow pelvis (MOL). Although the literature in the English language does not provide evidence to back up the abovementioned concern for suboptimal oncologic metrics in MOL, the study by Targarona et al. [3] brought to everybody's attention how the promontory-subsacrum angle of an android pelvis can affect oncological metrics when the resection is carried out laparoscopically. In fact, the shortcomings of a laparoscopic access to pelvic dissection for rectal cancer have been confirmed by two recent randomized control trials (RCT) (ACOSOG Z6051 and ALaCart), which concluded that laparoscopic resection is inferior to open surgery $[4,5]$. The main reason to trust these two RCTs has much more to do with the choice of histopathology endpoints (circumferential resection margin (CRM) and complete quality of TME) than with their random order design. In fact, two other RCTs (COLOR 2 and COREAN) concluded that

R Bergamaschi

rcmbergamaschi@gmail.com

1 Section of Colorectal Surgery, Department of Surgery, Westchester Medical Center, New York Medical College, Taylor Pavilion, Suite D-365, 100 Woods Road, 10595 Valhalla, NY, USA laparoscopic resection is non-inferior to open surgery based on survival rates, which as known are influenced by multiple factors (gene mutations, chemoradiation, etc.) and do not necessarily reflects the quality of surgery $[4,5]$. As it is unlikely that the results of the ACOSOG Z6051 and the ALaCart trials will bring us back to open surgery, one could speculate that the same results may indirectly turn the light onto robotic-assisted resection. In fact, a matched comparison of the first 20 robotic cases by the same surgeon showed that the width of the CRM was significantly improved (open $8 \mathrm{~mm}$ vs. laparoscopic $4 \mathrm{~mm}$ vs. robotic $10.5 \mathrm{~mm} ; p=0.02$ ) despite the learning curve [6]. A reasonable explanation seems to be that laparoscopic proctectomy may decrease the width of the CRM as a result of its restricted range of motion leading to a coning effect, which would be minimized by the improved ergonomics of the robotic wristed instruments [5]. The study by Barnajian et al. also concluded that the lack of tactile feedback did not adversely impact the quality of TME in the robotic cases [6]. Similarly, a pilot RCT had previously found no difference in TME quality comparing robotic to laparoscopic proctectomy [7].

Let us take a step back and provide the reader with an overview of the rationale behind coloanal anastomosing, which should be dictated by the location of the tumor rather than by surgical technique. The latter is namely the case of taTME. If the tumor does not involve the levator ani or external anal sphincter muscles, an intersphincteric resection (ISR) may be considered and the intestinal continuity restored with a hand-sewn coloanal anastomosis. William W. Babcock, and later Harry E. Bacon carried out such anastomoses in 1939 and in the 1960s as a part of a pullthrough operation. The technique for coloanal anastomosis we nowadays are familiar with was actually described by Alan G Parks in 1972 [8]. The fact that taTME would result in a very low anastomosis regardless of tumor location is particularly concerning when the International taTME 
Registry reports that $38 \%$ of 720 patients underwent taTME for tumors located at $10 \mathrm{~cm}$ (up to $13 \mathrm{~cm}$ ) from the anal verge with a $5-\mathrm{cm}$ distal resection margin [9]. In essence, taTME would have inflicted an unnecessary organ loss with the potential morbidity and functional disadvantages of a coloanal anastomosis [10]. Unlike the International taTME Registry's response [11], the New York State memorandum reads: "a learning curve is not a valid justification for patient injury" [12].

As early as in 2015 Warren and Solomon pointed out how (unlike ISR) taTME entails a rectal transection inside the pelvis, and thereby mandates serious scrutiny due to the potentially increased risk of local recurrence [13]. In January 2019, the National Norwegian taTME data were presented at the $9^{\text {th }}$ Ahus Colorectal Symposium, University of Oslo in Norway [14]. The results included not only an increased rate but also a new pattern of local recurrence in terms of its multifocality as well as its early timing after ta TME. On the basis of such alarming data, a consensus was reached to cease performing taTME in Norway [14].

The claim that taTME offers three oncologic advantages is regretfully flawed by another current state of affairs commonly referred to as spin, namely "misinformation by another name" [15]: (1) The data suggesting improved distal resection margins derive from a case series of 37 taTME patients by one surgeon compared to unmatched historical controls operated upon by several surgeons: $2.8 \pm 1.8 \mathrm{~cm}$ vs. $1.7 \pm 1.3 \mathrm{~cm} ; p<0.01$ [16]. The perception of improved distal resection margin was probably achieved carrying out unnecessary low rectal transections with coloanal anastomoses in patients with cancer of the mid rectum. In fact, a $1.7 \mathrm{~cm}$ distal resection margin would have been adequate. (2) An RCT reported a decreased rate of involved CRM following taTME ( 2 vs. $9 ; p=0.025$ ) despite there was no difference in the width of CRM ( $7 \mathrm{~mm}$ vs. $5 \mathrm{~mm} ; p=0.833$ ) [17]. The strength of this RCT was to include only patients with tumors located within the distal $6 \mathrm{~cm}$ of the rectum. Nonetheless, this trial was published in 2014 after enrolling patients from 2008 to 2012, was not registered in a publicly accessible trial database, and was underpowered with 100 patients despite a sample size of 590. (3) The data suggesting increased rates of complete TME quality derive from a case series of taTME patients operated upon by two surgeons and compared to matched historical controls: 24 vs. $18 ; p<0.05$ [18]. The $p$ value was calculated for the whole series including patients having undergone abdomino-perineal resection (APR). A comparison excluding APR cases would have resulted in a $p=0.229$ (Fisher exact test) and would have been more appropriate given that the plane of dissection differs in LAR and APR.

Although the International taTME Registry made a serious attempt to provide real world data on anastomotic leak rates [19], the focus has rather been on the intra-operative complications of taTME. In fact, unfamiliarity with the anatomy of a bottom-up view and/or cavalier attempts to carry out the dissection entirely from below might be behind urethra perforations and/or laceration of the internal iliac vein we heard through the grapevine. A recent study by Shen et al. [20] provided a substantial contribution in terms of emphasizing the value of MRI-based preoperative pelvimetry in essence taking the work of Targarona et al. [3] one step farther. Probably, the authors' most useful contribution was identifying the landmarks between the transanal and the transabdominal phases of the operation [20] as a reminder that taTME is not meant to replace but rather complement its abdominal counterpart.

Our unpublished data suggest that the width of CRM is not improved by taTME when compared to robotic TME. Therefore, it is appropriate to distinguish the genuine concern for suboptimal histopathology metrics in obese males undergoing transabdominal TME for low rectal cancer from the misuse of taTME for all patients with resectable rectal cancer regardless of gender or tumor location. We believe that the future of taTME would be short lived unless further research is conducted with rigorous methodology as unwarranted indication for taTME might at best inflict an unnecessary coloanal anastomosis.

Funding No funding.

\section{Compliance with ethical standards}

Conflict of interest The authors declare that they have no conflict of interest.

Research involving human participants and/or animals This article does not contain any studies with human participants or animals performed by any of the authors.

Informed consent For this type of study formal consent is not required.

\section{References}

1. Lisfranc J (1826) Mémoire sur l'excision de la partie inférieure du rectum devenue carcinomateuse. Rev Med Franc 2:380

2. Volkmann R (1878) Über den Mastdarmkrebs und die Exstirpatio recti [On rectal cancer and the exstirpatio recti]. Volkmanns Sammlung klinischer Vorträge III Serie 131:1113-1128

3. Targarona EM, Balague C, Pernas JC et al (2008) Can we predict immediate outcome after laparoscopic rectal surgery? Multivariate analysis of clinical, anatomic, and pathologic features after 3-dimensional reconstruction of the pelvic anatomy. Ann Surg 247(4):642-649

4. Tou S, Bergamaschi R (2016) Laparoscopic rectal cancer resection: inferior to open or not? Colorectal Dis 18(3):233 
5. Abbas SK, Yelika SB, You K et al (2017) Rectal cancer should not be resected laparoscopically: the rationale and the data. Tech Coloproctol 21(3):237-240

6. Barnajian M, Pettet D 3rd, Kazi E, Foppa C, Bergamaschi R (2014) Quality of total mesorectal excision and depth of circumferential resection margin in rectal cancer: a matched comparison of the first 20 robotic cases. Colorectal Dis 16(8):603-609

7. Baik SH, Ko YT, Kang CM et al (2008) Robotic tumor-specific mesorectal excision of rectal cancer: short-term outcome of a pilot randomized trial. Surg Endosc 22(7):1601-1608

8. Bergamaschi R, Larach SW, Pigazzi A, Marecik S, Valsdottir EB, Amrani S (2013) Laparoscopic colon and rectal surgery. In: Corman ML, Bergamaschi R, Nicholls RJ, Fazio VW (eds) Corman's colon and rectal surgery, 6th edn. Lippincott Williams \& Wilkins, Philadelphia, p 546

9. Penna M, Hompes R, Arnold S et al (2017) Transanal total mesorectal excision: international registry results of the first 720 cases. Ann Surg 266(1):111-117

10. Gachabayov M, Chudner A, Bergamaschi R (2018) A succinct critical appraisal of indications to transanal total mesorectal excision. Ann Surg 268(6):e94

11. Hompes R, Penna M, Tekkis PP (2018) A succinct critical appraisal of indications to transanal TME. Ann Surg 268(6):e94-e95

12. State of New York Department of Health Memorandum-Series 92-20, 6/12/1992. https://www.health.ny.gov/professionals. Accessed 1 Feb 2019

13. Warren OJ, Solomon MJ (2015) The drive toward transanal total mesorectal excision-science or rhetoric? Dis Colon Rectum 58(9):909-910

14. Larsen S (2019) Is taTME the final solution? In: 9th Ahus colorectal symposium, University of Oslo, Norway, 24-25 January 2019
15. Fingerhut A (2015) Medical SPIN: misinformation by another name. Surg Endosc 29(6):1257-1258

16. Fernandez-Hevia M, Delgado S, Castells A, Tasende M, Momblan D, Díaz del Gobbo G et al (2015) Transanal total mesorectal excision in rectal cancer: short-term outcomes in comparison with laparoscopic surgery. Ann Surg 261:221-227

17. Denost Q, Adam JP, Rullier A, Buscail E, Laurent C, Rullier E (2014) Perineal transanal approach: a new standard for laparoscopic sphincter-saving resection in low rectal cancer, a randomized trial. Ann Surg 260:993-999

18. Velthuis S, Nieuwenhuis DH, Ruijter TEG, Cuesta MA, Bonjer HJ, Sietses C (2014) Transanal versus traditional laparoscopic total mesorectal excision for rectal carcinoma. Surg Endosc 28:3494-3499

19. Penna M, Hompes R, Arnold S et al (2018) Incidence and risk factors for anastomotic failure in 1594 patients treated by transanal total mesorectal excision: results from the International TaTME Registry. Ann Surg. https://doi.org/10.1097/sla.000000000000265 3 (Epub ahead of print)

20. Shen Z, Cheng J, Yin M et al (2018) Evaluation of anatomical landmarks for transanal total mesorectal excision based on MRI. Asian J Surg. https://doi.org/10.1016/j.asjsur.2018.10.003 (Epub ahead of print)

Publisher's Note Springer Nature remains neutral with regard to jurisdictional claims in published maps and institutional affiliations. 